\title{
Adopting Industry Based Curriculum Design towards Independent Campus Policy
}

\author{
Gozali Gozali, Ria Setyawati, Bambang Jati Kusuma, Fitriyani Fitriyani \\ State Polytechnic of Balikpapan \\ Corresponding Authors: fitriyani@poltekba.ac.id
}

\begin{abstract}
The relevance of the curriculum between vocational education (diploma) and industry needs is still a matter in the world of education in Indonesia. This happens the link and equivalent in the preparation of the education curriculum have not existed. The Indonesian government through the policy of an independent learning and independent campus learns to create appropriate curriculum designs between vocational education and industry. This research is to find out the industrial curriculum design for diploma graduates. The methodology used a study by finding theoretical references that are relevant to the topic and sought through descriptive analysis. the right and appropriate partnership, it can produce curricula based on the industry required by student competencies in four categories, namely (1) Core foundations, (2) Concentrations (3) Experiences (Industry Experience and Internship), (4) Final Projects. These four categories provide an increase in student competencies that are in line with industry needs.
\end{abstract}

Keywords: Industry based curriculum; Diploma graduates; Partnership; Core competence; Final project

\section{INTRODUCTION}

Globalization can create a variety of challenges and new problems that must be resolved, especially in the field of quality human resources which is currently one of the fundamental matters of this nation. It becomes an increasingly difficult challenge for the world of education, how to build the quality of Indonesian people who deal with these challenges. Data from the 2017-2018 Global Competitiveness Index (GCI) shows the level of competitiveness of the Indonesian people ranks 36th out of 137 countries on the CGI list. This sequence is still under Singapore (3), Malaysia (23), Thailand (32). Meanwhile, data on the Human Development Index in 2015 shows that Indonesia ranks 113 out of 188 countries and Indonesia ranks fifth at the ASEAN level, below Singapore, Brunei, Malaysia, Thailand.

The low competitiveness and the Human Resources Development Index indicate that there are matters in the education delivery system, especially higher 
education in Indonesia. The cause of matter identified is the relevance of higher education to the needs of the world of work and industry which is the cause of the high unemployment rate of educated workers. The relevance of vocational education is not only caused by the gap between "supply" and "demand" but also be caused by curriculum content that is not under the demands of the world of work, science and technology development and economic development (Tilar, 1991). Therefore, education, curriculum and learning reform always be carried out from time to time and never stop. Education, curriculum, and competency-based learning are examples of the results of these changes to improve the quality of education and learning (Mukminan, et.al. 2008).

Based on data compiled by the Institute for Development of Economics and Finance (INDEF), the rate of decline in unemployment in Indonesia has been slow since 2012 (INDEF, 2019). In 2018, unemployment in Indonesia was recorded at 7,000,691 people or $5.34 \%$ of the total workforce. That number has decreased slightly compared to the open unemployment rate in 2017 of $7,040,323$ people or $5.5 \%$ of the total workforce. Based on INDEF records, the number of unemployed vocational graduates rose from around 1 million in 2012 to 1.7 million in 2018. Meanwhile, unemployed educational higher graduates increased from 400,000 to 700,000. INDEF researcher Ahmad Heri Firdaus suspects that there is a possibility that the skills or skills possessed by vocational education graduates are not by current industry needs.

Vocational education is required specifically to prepare graduates to become experts, ready to work, easy to adapt to the environment and change, and able to develop themselves by the needs of the workforce. The Ministry of Education and Culture, through the Directorate General of Vocational Education, allocates a budget of Rp. 3.5 trillion for vocational education development programs. The budget allocation would be used to realize the link and match between vocational education with the business world and industry into 5 packages that are the main pillars in the link and match process, including first, a curriculum prepared by the two parties. Second, guest lecturers teach at least 50-100 hours per semester from competent experts and professional practitioners from the industry and the world of work. Then third, is an apprenticeship designed from the start. Fourth, the uptake of graduates. Fifth, vocational lecturers also receive training or technology updates from the industry.

The link and match between the curriculum used and industry needs is the earliest and becomes the most important effort to resolve this gap. To ensure that vocational students are adequately prepared to meet future industrial and technological advancements, The Indonesian government has issued a policy related to an independent campus and free learning. This policy has implications for significant changes ranging from curriculum development, teaching strategies and introduction to new technologies in the classroom while providing an additional experience for students. Given the applied nature of diploma graduates discipline, it is essential to solicit strategic advice on curriculum design from industry (Cooper \& 
Westlake, 1998). This input ensures that core competencies are being met and that graduates will have the necessary skill sets for employment (Peacook \& Ladkin, 2002). Additionally, beyond curriculum design, a close relationship with industry is vital for internships and job placements, student projects, faculty research and consultancy opportunities, among other things (Peacook \& Ladkin, 2002). Hence, the role of industry in assisting with curriculum development is critical, and academia worldwide has increasingly garnered the needed input and demonstrated its utility (Cooper \& Westlake, 1998).

In this context, this article presents a detail description of concept of adopting Industry Based curriculum Design. Academic-industry linkages deal with curriculum development have been non- existent in the country. More specifically, the designed core competency matrix with five categories - intellectual abilities, technical skills, industry knowledge, interpersonal skill, and professional skill - were employed as a key instrument (Cooper \& Westlake, 1998). The sections that follow first outline the partnership background, followed by the process and the final curriculum product.

\section{METODOLOGY}

This research belongs to the type of literature review research by finding theoretical references relevant to the case or problem found. The Literature review is a written summary of articles from journals, books, other documents that describe theories and information both past and present, organizing literature into topics and documents needed. The type of data used by the author in this study is data obtained from literature studies. The literature study is a method used to collect data or sources relating to the topics raised in a study. The data obtained is then analyzed by descriptive analysis method [6]. The Descriptive analysis method, describing the facts which are then followed by the analysis, not merely describing, but also providing sufficient understanding and explanation.

In this study, the researcher analyzes the references of industrial partnership, find out the industry-based curriculum model and describes them from references chosen. Discussion about credit conversion and competence category

\section{RESULT}

\section{Curriculum Development}

The new education paradigm of education in Indonesia today is that no curriculum is valid forever (Munandir, 2001). The curriculum is dynamic in the sense that the curriculum must be reviewed continuously. It is due to the understanding of education that demands to produce graduates with programs that are in line with industry expectations. Compliance with the demands of the business and the industrial world becomes an important aspect of curriculum development. If the prepared curriculum 
is not following the needs of industry. it can be said that the curriculum has no benefit. In other words, the curriculum must be following the development of science, technological development, the demands of the age, and anticipation of future trends. The changes in the curriculum made are based on recommendations from the assessment results. It means the implementation of the curriculum is considered to have failed in achieving its objectives, no longer in line with the demands of the times because there has been a change in society, for example, changes in governance from the government exists. Curriculum changes can cover all aspects ranging from objectives, design, content, scope, and assessment. The meaning of change in the world of education is a change in curriculum context and changes in what lecturers do (Kelly, 1979). He outlines the determinants of change in implementing the curriculum are stakeholders consisting of teachers, principals, educational consultants, the community includes students and the government.

Higher education, as an educational institution, needs to build a curriculum that is following market needs. The experts describe taxonomy that presents the relationship between suppliers and users in choosing the needs of facilities, choosing the construction of higher education needs, and then integrating between improving tertiary education and planning for vocational education. The depiction of the taxonomy of user and supplier relations in higher education by (Conny, et.al. 2005) varying mission and objectives as follows:

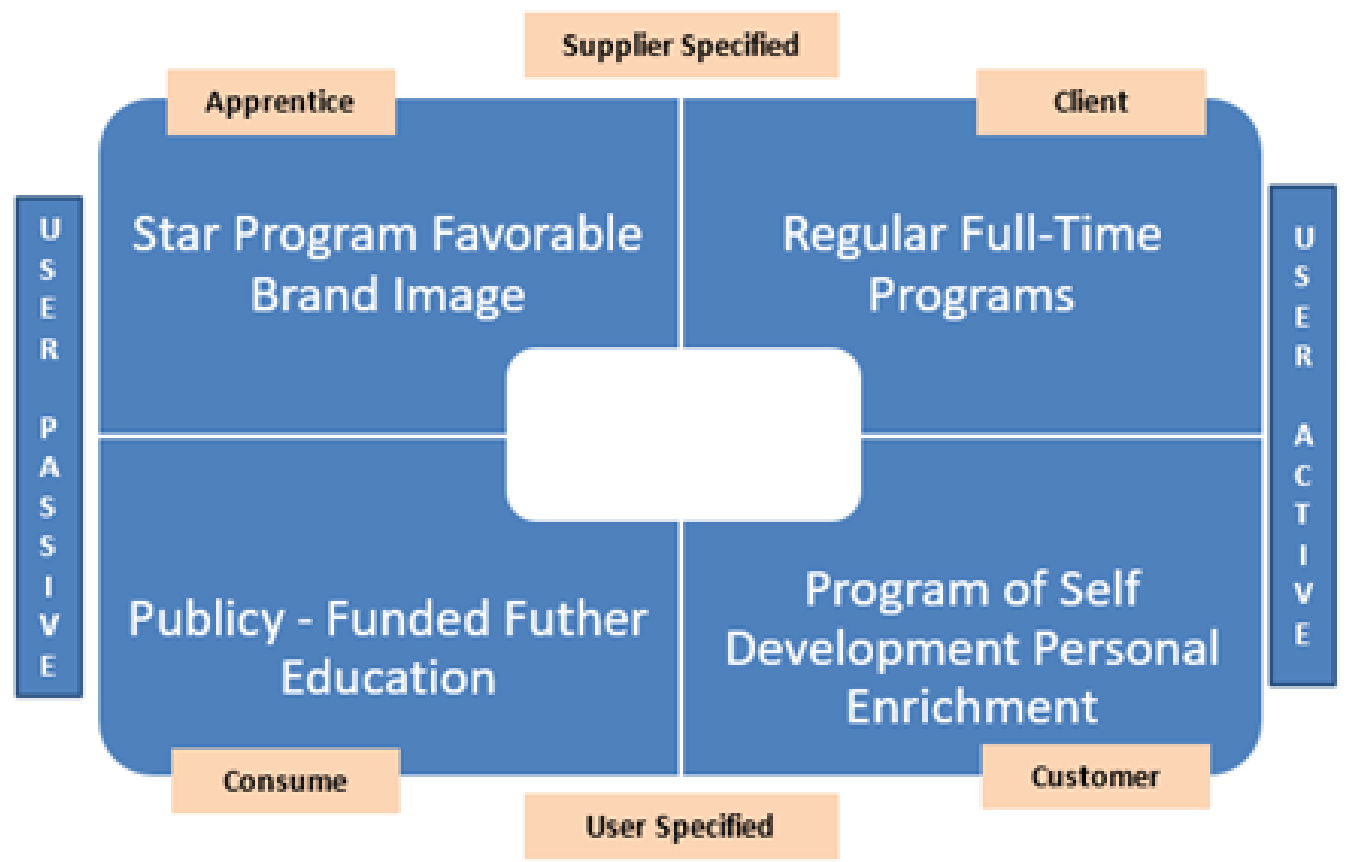

Picture 1. The relevance of supplier and user in higher education 
The Classification relationship system between supplier and user quadrants in higher education is divided into 2 namely passive users and active users. It illustrates passive users can be done with apprentices (starting the program by the brand image specifications supplier) and adjusting consumption ( by educating following user specifications. The active users did with clients (doing regular full-time programs based on supplier specifications and customer programs (with personal enrichment tailored to user specifications). The above paradigm also explains that in basically the relationship between the two pathways namely the world of education and the demands of the world of work there is no rigid separation wall (Conny, et.al. 2005).

\section{Industry Based Curriculum Design}

The vocational education curriculum is based on training or improvement through certain competency standards namely Permendikbud Number 3 of 2020 concerning Higher Education National Standards. The parent of the SNPT is the graduate competency standard (SKL), where each competency must refer to the Indonesian National Work Competency Standards. The concept of Indonesian Competency Standards was developed by stakeholders and established by the government through the Ministry of Manpower. The development processes done are through several methods include adapting and adopting, benchmarking, and combination. While users of competency standards are the world of work and industry, formal and non-formal education, and stakeholders. The sustainability of the development of an industry-based curriculum must always be maintained in the form of productive cooperation. The concept of link and match between established competency standards, vocational education, and industry can be illustrated in the picture below:

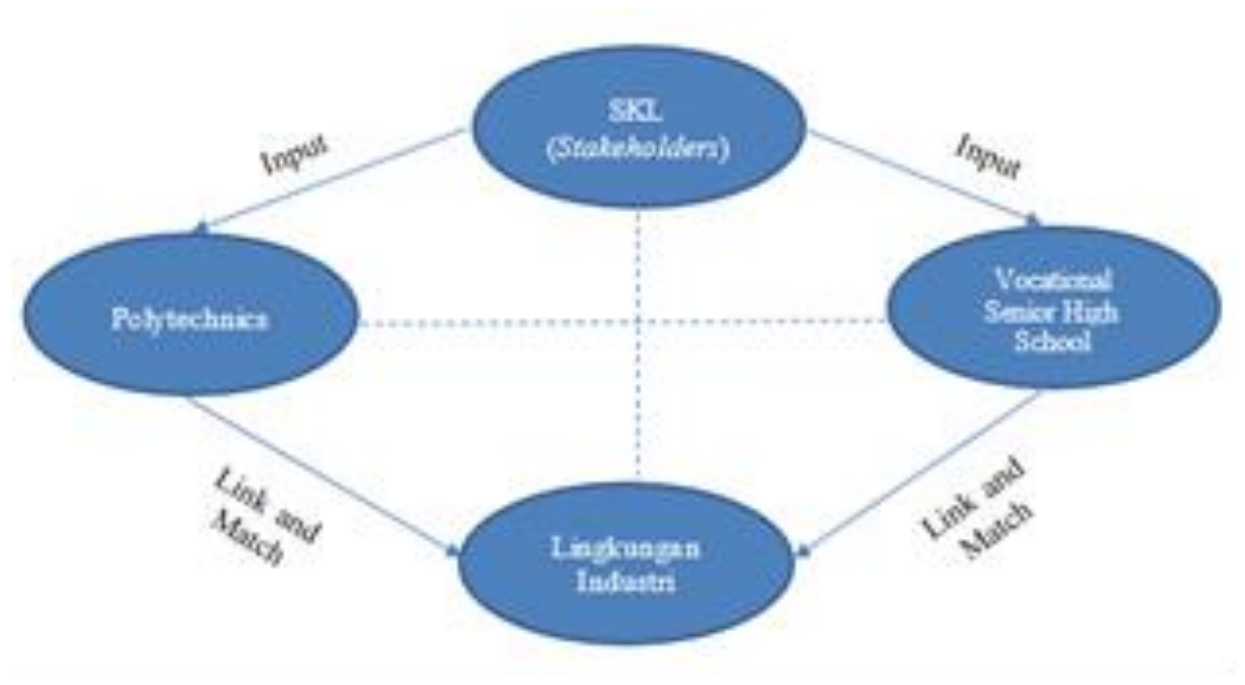

Picture 2. The chart of link and match amongs stakeholders (government, society), vocational high school, polytechnics, and industry 
From the chart above, it is illustrated that to create a link and match with the industry requires synergy between stakeholders (government, society), industrial environment, and polytechnics. The synergy is also needed to create an industrybased curriculum to strengthen diploma graduates. The sections describe the outline linkage among the partnerships (industry), followed by the final curriculum product.

\section{Partnership}

The polytechnics and industry should collaborate in mutualism partnerships to overcome the limited budget for providing quality education in the future in various forms. One form of potential collaboration is the Zinser Model (Mahews, et.al. 1984) which introduces partnerships between polytechnics and industry to earn funds based on different needs and interests. The intended partnership strategy is realized in the form of A Typology of Industry-Academica Collaboration which consists of 6 types: (1) Contributions, (2) Purchases (Procurements), (3) Networks, (4) Exchanges, (5) Cooperative, and (6) Joint Venture:

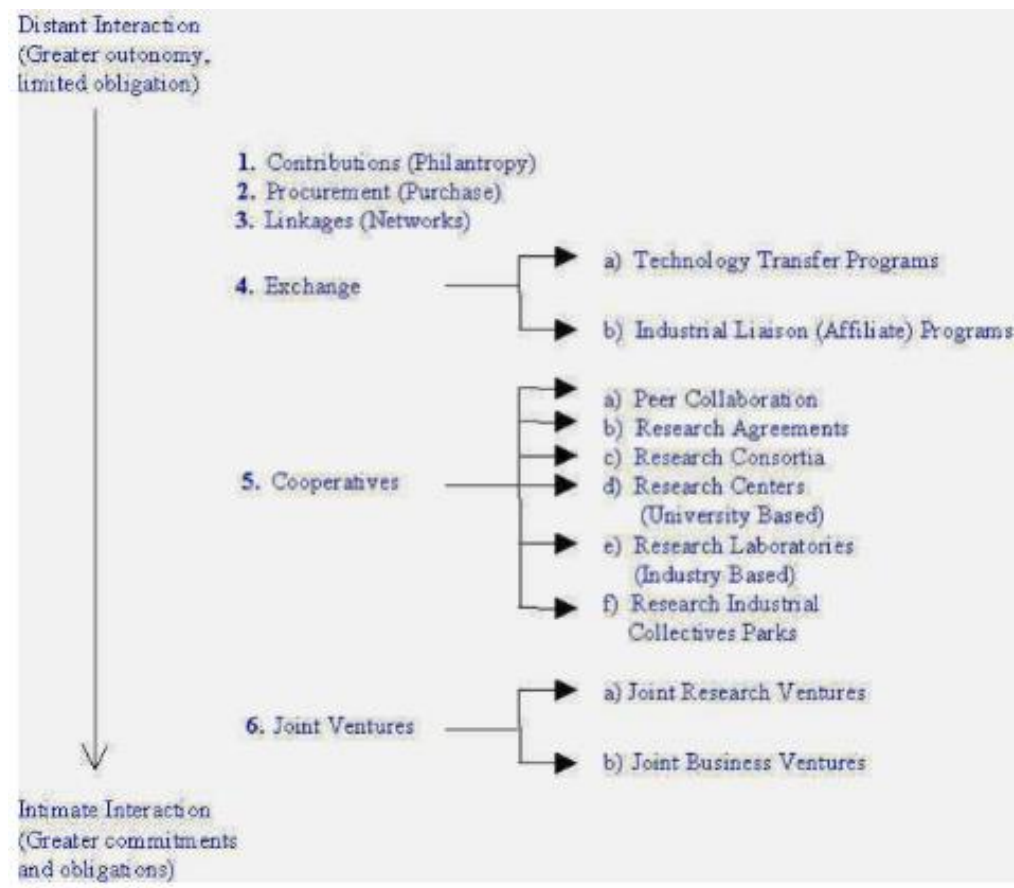

Picture 3. Zinzer partnership model

(1) Contribution. This type of cooperation is a partnership agreed between each party that contributes to and voluntary participation. For example, the industry contributes in the form of funds and equipment to universities, in contrast, universities can contribute services and research results to the voluntary industry. (2) Procurement. Through this type, industry services can be purchased that have the advantage of expertise or equipment, while the industry can spend funds to get product testing, 
education, and training services from universities. (3) Network. This type is a transition that forms communication and problem solving between the two parties (universities and industry) he called the network. Informal networks to safety ratings can be created through this network. one model of this type is the establishment of a sponsoring office that conducts research and other research. Besides, activities that form a liaison are carried out in the department or faculty that are intended to establish good communication. One of the successful findings in this field is in Japan which relies on personal relationships. The lecturers are active in the process of recruiting experts for industry and establishing close relationships between alumni who work in the industry with intensive lecturers (Sonhadji, 1992). (4) Exchange. This type of transfer that leads to formal in the fields of trade, assets, and transfer of knowledge between universities and industry. This transfer program can consist of: a. technology transfer program (discovery) from universities to industry to be commercialized, the imbalance of higher education gets royalties, $b$. the affiliate program is a university providing access to experts for industry and universities getting funding from that access. (5) Cooperatives. In this model, several collaboration models are ranging from simple to complex. The agreed collaboration model is published: (a) Peer collaboration (researchers and industry support for joint research on a variety of themes or topics highlighted by both parties), (b) collaborative research between universities and industry, (c) Relationships of universities involved in industrial research, (d) tertiarybased research centers, (e) industrial-based laboratories, (f) tertiary institutions. (6) Joint ventures. Strategies in this type must still be followed up by universities to develop partnerships with industries under their capabilities. Besides, there are still many renewals of partnerships that can be developed with other parties. The implication is that if partnership programs can be saved, the imbalance from other parties to universities can be increased in a relatively long time.

\section{Industry Curriculum Product}

The emphasis of the curriculum is on content and industry knowledge, skills development and practical experience. More importantly, the role of industry stakeholders was heavily weighted to integrate core competencies for graduates with respect to employable skills. The form of curriculum consisted of four major categories that were linear building blocks culminating in a final project and a 6-month full-time internship (Thapa, 2018). The four categories were: (1) Core foundations, (2) Concentration (3) Experiential (Industry Experience and Internship), (4) Final Project.

1. Core foundations. This category provides a strong core foundation knowledge in the areas of general subjects.

2. Concentration. This category provides disciplines-specifics foundations and applied knowledge. 
3. Experiential. The applied (practical) component is an integral part of the learning process. Given the nature of the diploma (3 or 4 years) graduates, students are required to obtain experience during their third and fourth years. Two levels of attachment are required: industry experience and internship.

Industry experience. The aim of this exercise is to expose students to the industry. Industry experience, during the third (3 years diploma) or fourth (four years diploma), is designed to engage students in situations in a professional setting that is complementary to their academic coursework. The completion of a three-step process is necessary to fulfil the requirement. First, students identify and seek approval from the industry. Second, on approval, they begin to volunteer part-time for a total of 192 hours ( 8 hours per week for 6 months). Third, they submit a completion report and verification forms to ensure attendances and record work accomplished.

Internship. The Internship program builds on the prior industry experience and supporting core and specialization coursework. It is a cornerstone of the academic and applied learning process and is mandatory for all students. The fulfilment of a threestep process is required for degree completion. First, students identify and seek approval from the industry and the academic program coordinator. The approval process entails submission of a plan of work (weekly assignment) to be completed at the establishment. The details must be vetted and approved by the establishment and the academic coordinator. Second, on approval, they begin an official full-time engagement for a total of $960 \mathrm{~h}$ ( $40 \mathrm{~h}$ per week for 6 months). Third, a report along with forms to verify attendance and work completed is required. The final report should include an overview of the assignments completed, lessons learned and observations and experiences in the professional work environment.

Final Project. The final project serves as the final requirement for completion. A report must be submitted at the end of the final semester and must include a statement of purpose, professional documentation, knowledge integration and application and program review and feedback.

Table 1. Curriculum Summary

\begin{tabular}{|l|c|c|}
\hline $\begin{array}{c}\text { Curriculum } \\
\text { categories }\end{array}$ & $\begin{array}{c}\text { Number of } \\
\text { Courses }\end{array}$ & $\begin{array}{c}\text { Number } \\
\text { of Credits }\end{array}$ \\
\hline Core foundations & 24 & 72 \\
\hline Concentration & 10 & 30 \\
\hline Experiential & 5 & 15 \\
\hline Final Project & 1 & 3 \\
\hline
\end{tabular}


The curriculum could beyond the traditional content based lecture format and represented, rather, a process based approach focusing on the actual progression of learning (Cooper \& Westlake, 1998). Hence, multiple methods were recommended, such as lectures and discussions, seminars, presentations, case studies, individual and group activities, projects, field visits and invited industry guest speakers. The next phase is to hire faculty to teach the courses. It will be important to recruit individuals with five or more years of industry experience. The rationale is to ensure the credibility of the instructors with respect to content knowledge, industry networks and managerial expertise:

\section{CONCLUSION}

Industry based curriculum development is the earliest and foremost effort to resolve the gap of diploma graduates with the needs of the industrial market is still a problem in Indonesia. The link and match effort between the curriculum used and the industry's needs have not happened to make the lack of industry concern for higher education becomes not optimal. The curriculum produced through direct involvement will be able to overcome problems related to curriculum relevance, thereby helping diploma program graduates have competencies that can be applied directly in industry. To produce such a curriculum. However, the new relationships formulated during the curriculum development process needs to be fostered and strengthened through good partnerships. The type of partnership chosen will also affect.

Overall, this article encapsulates an academic partnership between industry and vocational education, especially for polytechnic as diploma graduates' producers. As outlined, the role of industry in the curriculum development process is important. This institutional collaboration is made possible, which is unique in its flexibility and its ability to provide intellectual and financial resources to assist higher education institutions in developing countries for capacity building and institutional development. It takes the concept of partnership between the field and an institution beyond just the provision of fieldwork placements, while undoubtedly leading to increased placement opportunities. It is important as it assists the institution to create the industry curriculum. We are confident that this industry curriculum design will have a positive influence on the social work practice culture industry within knowledge, skills development and practical experience Overall, we hope that our experience offers some encouragement that partnerships such as this do matter and can advance the interests of both the university and the field. We look forward to reviewing the achievements of this industry curriculum design in a few years' time and we are confident that this is a design that could have wide applicability throughout the vocational education sector in Indonesia. 


\section{REFERENCES}

Conny Semiawan, Th. I. Setiawan and Yufiarti, (2005). "Panorama Filsafat Ilmu, Landasan Perkembangan Ilmu Sepanjang Zaman", Seri Buku Daras.

Cooper C and Westlake J (1998). Stakeholders and tourism education. Industry \& Higher Education 12(2): 93-100.

INDEF. Institut for Development of Economics and Finance. (2019) In: Report of a news on Ekonomi.Bisnis.com. Jakarta, Indonesia: INDEF; R. Lalu, “Title of paper if known," unpublished.

Kelly A.V. (1979). The Curriculum, London: Harper \& Row Ltd.

M. Young, (1989). The Technical Writer's Handbook. Mill Valley, CA: University Science.

Matthews, Jana B and Norgaard, Rolf. (1984). Managing the Partnership between Higher.

Mukminan, Waras K., Herminarto S. (2008). Panduan Pengembangan Model Pembelajaran Berbasis Kompetensi. Jakarta: Dikti.

Munandir. (2001) Esiklopedia Pendidikan, Malang: UM Press, 2001.

Peacock N and Ladkin A (2002) Exploring relationships between higher education and industry. Industry \& Higher Education 16(6): 393-401.

Sonhadji, K.H. Ahmad. (1992). Hubungan Simbiotik antara Perguruan Tinggi dan Industri : Implikasi terhadap Strategi Pengelolaannya. Pidato Ilmiah disampaikan.

Thapa B. (2018) Industry involvement in curriculum development: A case study in Nepal. Journal of Industry and Higher Education 32 (3): 200-206.

Tilaar, H.A.R. (1991). "Sistem Pendidikan Yang Modern Bagi Pembangunan Masyarakat Industri Modern Berdasarkan Pancasila". Makalah pada KIPNAS V September 1991, Jakarta. 